\title{
EKSISTENSI JEJARINGAN FAKULTAS ILMU PENDIDIKAN-JURUSAN ILMU PENDIDIKAN (JIP-FIP) DALAM PENINGKATAN KUALITAS GURU DAN TENAGA KEPENDIDIKAN INDONESIA MENUJU INDONESIA EMAS 2045
}

\author{
(Oleh : Prof. Dr. Firman. MS. Kons. Dekan FIP Universitas Negeri Padang) \\ Email: firman@konselor.org
}

\begin{abstract}
Networking between FIP-JIP in the development of quality human resources at various levels and access to education has not run its full potential in improving the quality of graduates. This paper aims to describe the importance of networking FIP-JIP in the development of quality graduates in the face of global competition. Quality education and relating to the achievement of competency in accordance with the standards expected, by implementing a reliable quality assurance system. FIP-JIP networking across Indonesia in the implementation of quality education includes an integrated working system as a whole. FIP-JIP network is a system of relations between universities governed and ordered by various forms of agreement that enables communication and transmission of information on an ongoing basis, exchange of expertise and other resources. FIP-JIP networking will benefit in providing more recent information can be used flexibly and as needed in the development of quality graduates.
\end{abstract}

\section{A. Pendahuluan}

Pembangunan pendidikan merupakan salah satu aspek penting dan strategis sebagai penentukan kualitas sumber daya manusia (SDM) Indonesia. Keberhasilan pembangunan pendidikan diharapkan dapat memberikan kontribusi terhadap kemajuan masyarakat secara menyeluruh dalam menghadapi persaingan global. Memasuki Abad 21 bangsa Indonesia dituntut menyiapkan SDM berkualitas dengan keunggulan kompetitif yang dapat diperoleh melalui pendidikan yang bermutu. 
Menyadari akan pentingnya mutu pendidikan dalam penyiapan SDM berkualitas, dewasa ini pemerintah menaikan anggaran pendidikan. Peningkatan alokasi anggaran ditujukan untuk meningkatan mutu, dengan ketersediaan sarana, fasilitas laboratorium, peralatan, perpustakaan dan buku yang memadai serta pendidik dan tenaga pendidik yang berkualitas. Di sisi lain, peningkatan alokasi anggaran juga ditujukan memperluas akses pendidikan agar seluruh masyarakat dapat memperoleh kesempatan yang sama.

Perwujudan mutu serta perluasan akses pendidikan, dewasa ini pemerintah berupaya meningkatkan kualitas dan relevansi perguruan tinggi agar mampu bersaing secara global. Tantangan globalisasi, otonomi institusi dan tuntutan kualitas berstandar internasional telah menghasilkan paradigma baru dalam pengembangan pendidikan tinggi. Kebijakan pengembangan perguruan tinggi tahun 2003 - 2010 yang dikemas dalam dokumen Higher Education Long Term Strategy (HELTS), dengan strategi utama untuk meningkatkan daya saing bangsa, otonomi institusi dan kesehatan oranganisasi. Dewasa ini sasaran yang ingin dicapai perguruan tinggi, mengacu kepada Renstra Kemendiknas 2010 - 2014 yang memberikan penekanan pada peningkatan (5K), yaitu : (1) ketersediaan, (2) keterjangkauan, (3) kualitas dan relevansi, (4) kesetaraan, dan (5) kepastiaan. Sehubungan dengan hal itu, program yang dilaksanakan diharapkan terjadinya peningkatan mutu yang ditandai : (1) meningkatnya indeks prestasi komulatif (IPK) mahasiswa, (2) makin pendeknya masa studi mahasiswa, (3) meningkatnya jumlah peminat calon mahasiswa, (4) makin singkatnya penyelesaian tugas akhir mahasiswa, (5) meningkatnya jumlah lulusan yang diterima di dunia kerja, (6) meningkatnya jumlah dan kualitas fasilitas belajar, (7) meningkatnya mutu layanan, (8) meningkatnya jumlah staf pengajar yang mengikuti studi lanjut, (9) meningkatnya kualitas dan kuantitas penelitian dan pengabdian kepada masyarakat, (10) meningkatnya kemampuan staf administrasi, (11) meningkatnya kesejahteraan mahasiswa, 
(12) meningkatnya golongan jabatan fungsional staf pengajar, dan (13) semakin kondusifnya suasana akademik.

Keberhasilan dan kemajuan perguruan tinggi tidak dapat diukur melalui kuantitas lulusan saja, tetapi diukur bila perguruan tinggi tersebut menghasilkan intelektual yang dapat berpartisipasi dalam pembangunan masyarakat. Selama ini Fakultas Ilmu Pendidikan atau Jurusan Ilmu Pendidikan dari berbagai perguruan tinggi di Indonesia telah berperan dalam menghasilkan lulusan, yang sebagian besar telah bertugas dan memberikan kontribusi dalam pelaksanaan pendidikan diberbagai instansi pemerintah dan swasta. Keberadaan alumni FIP-JIP, sangat berarti dalam menunjang pengembangan SDM melalui pelaksanaan pendidikan berkualitas di lingkungan pendidikan formal, informal dan non formal. Selanjutnya Fakultas Ilmu Pendidikan atau Jurusan Ilmu Pendidikan dari berbagai perguruan tinggi juga telah menjalankan fungsinya sebagai pusat pengembangan ilmu pendidikan serta rujukan publik atas segala permasalahan pendidikan.

Pemimpin fakultas/jurusan/program studi masa depan sebagai pengelola sistem manajemen mutu, pada hakikatnya berintikan perbaikan terus menerus untuk memperkuat dan mengembangkan mutu. Kebutuhan lokal/nasional/global menuntut FIP-JIP untuk lebih cermat dan menentukan wawasan ke depan, didasarkan atas pertimbangan potensi, kendala, peluang dan ancaman. Sebagaimana kita ketahui bersama, era globalisasi adalah era persaingan mutu. Sehubungan dengan hal itu, FIP-JIP di era globalisasi harus berbasis mutu. Mahasiswa yang menuntut ilmu di fakultas ini sesungguhnya mengharapkan hasil dari komunikasi dan motivasi ganda, yaitu ilmu pengetahuan, gelar, keterampilan, pengalaman, keyakinan dan perilaku luhur. Semuanya itu diperlukan sebagai persiapan memasuki dunia kerja atau membuka lapangan kerja dengan mengharapkan kehidupan lebih baik dan sejahtera. 
Berbagai tantangan akan dihadapi FIP-JIP ke depan, diantaranya: peningkatan proses dan kualitas pendidikan, ketersediaan dan keterjangkauan layanan akademik yang memadai, kualitas dan relevansi pendidikan, penyediaan dosen dan tenaga kependidikan bermutu, penelitian dan pengabdian kepada masyarakat dan dukungan manajemen dan pelaksanaan tugas teknis yang bermutu, kerjasama dengan lembaga dalam dan luar negeri, peningkatan kesejahteraan dosen berserta tenaga kependidikan lainnya.

Kenyataan dewasa ini menunjukan, mutu pendidikan bangsa Indonesia belum mencapai hasil yang diharapkan bersama, baik menurut penilaian Internasional maupun penilaian masyarakat Indonesia sendiri. Pembangunan sarana-prasarana fisik sekolah puluhan tahun lalu tidak dibarenggi oleh peningkatan mutu lulusan. Revisi kurikulum yang telah berkali-kali dilakukan tidak membuahkan praktek pembelajaran dan UN yang lebih baik. Desentralisasi penyelenggaraan pendidikan dengan Komite Sekolah dan Dewan Pendidikan serta perubahan strategi pembelejaran pun tampaknya belum menunjukkan tanda-tanda akan membaiknya mutu pendidikan di tanah air. Perbaikan mutu lulus FIP-JIP sangat tergantung dengan penguatan jejaringan atar perguruan tinggi yang ada dalam mendukung peningkatan kualitas pendidikan Indonesia.

\section{B. Perubahan Tuntutan Masyarakat terhadap Lulusan FIP-JIP}

Di era globalisasi dan teknologi infomasi, masyarakat Indonesia membutuhkan guru dan tenaga kependidikan yang profesional, berkualitas, serta sebanding dengan kualitas guru dan tenaga kependidikan negara lainnya di dunia. Berbagai kebijakan sudah dilakukan pemerintah dalam peningkatan profesionalisasi guru, diataranya: peningkatan kualifikasi pendidikan dari Diploma menjadi S1, sertifikasi, dan sebagainya. Profesi guru merupakan jabatan atau pekerjaan yang mempersyaratkan keahlian, etika dan organisasi profesi yang mewadahinya. 
Kompetensi yang diharapkan dari guru profesional di Indonesia dewasa ini, sebagai agen pembelajaran, meliputi: kompetensi pedagogik, kepribadian, sosial, dan professional. Michael D. Bayles (1981) mengemukakan beberapa ciri profesi sebagai berikut: (1) perlunya training atau pendidikan untuk mempraktekkan profesi, (2) training atau pendidikan mencakup komponen intelektual yang memadai, (3) memiliki kemampuan yang telah terlatih memberikan layanan, (4) adanya sertifikasi atau lisensi untuk status profesional, (5) adanya organisasi profesional yang menampung para anggota, serta (6) adanya otonomi dalam melaksanakan pekerjaan.

Undang-Undang yang mengatur tentang Guru dan Dosen (Bab III Pasal 5) menjelaskan tentang prinsip profesional profesi guru mencakup: (1) memiliki bakat, minat, panggilan jiwa, dan idealism, (2) memiliki kualifikasi pendidikan dan latar belakang pendidikan sesuai bidang tugas, (3) memiliki kompetensi yang diperlukan sesuai dengan bidang tugas, (4) memiliki ikatan kesejawatan dan kode etik profesi, (5) bertanggungjawab atas pelaksanaan tugas keprofesionalan, (6) memperoleh penghasilan yang ditentukan sesuai dengan prestasi kerja, (7) memiliki kesempatan untuk mengembangkan profesi secara berkelanjutan, (8) memiliki jaminan perlindungan hukum dalam melaksanakan tugas keprofesionalan, (9) memiliki organisasi profesi yang mempunyai kewenangan mengatur hal-hal yang berkaitan dengan keprofesian guru.

Berdasarkan uraian tersebut, terlihat bahwa guru profesional harus memiliki karakteristik tertentu dan berkembang sesuai dengan persyaratan yang dituntut oleh masyarakat penggunanya. Tuntutan terhadap guru profesional semakin dirasakan oleh peserta didik, karena guru berperan sebagai manager pembelajaran bagi peserta didiknya. Segala sesuatu yang berkaitan dengan kegiatan pembelajaran di dalam kelas menjadi wewenang dan tanggungjawab guru. Sumber-sumber belajar yang akan digunakan dalam pembelajaran sepenuhnya berada di tangan guru. Begitu juga metode, 
materi pembelajaran yang akan diterapkan di dalam kelas, juga menjadi tanggungjawab guru.

Kemajuan teknologi informasi dan komunikasi (TIK) telah memberikan pengaruh dalam proses pembelajaran. Rosenberg (2001) menjelaskan dengan berkembangnya penggunaan TIK ada lima pergeseran dalam proses pembelajaran, yaitu: (1) dari pelatihan ke penampilan, (2) dari ruang kelas ke di mana dan kapan saja, (3) dari kertas ke on line atau saluran, (4) fasilitas fisik ke fasilitas jaringan kerja, (5) dari waktu siklus ke waktu nyata. Komunikasi sebagai media pendidikan dilakukan dengan menggunakan media komunikasi , seperti: telepon, komputer, internet, e-mail dan sebagainya. Interaksi antara guru dan siswa tidak hanya dilakukan melalui hubungan tatap muka tetapi juga dilakukan dengan menggunakan media baik di kelas maupun di luar sekolah.

Dewasa ini, Guru dan tenaga kependidikan lainnya dapat memberikan layanan tanpa harus berhadapan langsung dengan peserta didik. Begitu juga sebaliknya, peserta didik dapat memperoleh informasi dalam lingkup yang luas dari berbagai sumber melalui cyber space atau ruang maya dengan menggunakan komputer atau internet. Hal yang paling mutakhir adalah berkembangnya apa yang disebut cyber teaching atau pengajaran maya, yaitu proses pengajaran yang dilakukan dengan menggunakan internet. Istilah lain yang makin populer saat ini ialah e-learning yaitu satu model pembelajaran dengan menggunakan media teknologi komunikasi dan informasi khususnya internet.

Setelah terjadinya kemajuan teknologi informasi dan komunikasi dalam pembelajaran, berbagai permasalahan dihadapi oleh guru serta tenaga pendidik lainnya. Permasalahan yang dihadapi saat ini, masih berada pada tingkat kesiapan peserta didik, guru dan tenaga pendidik, infrastruktur sekolah, pembiayaan, efektifitas pembelajaran, sistem penyelenggaraan dan daya dukung dalam menyelenggarakan pembelajaran berbasis TIK. 
Pengadaan media TIK untuk kegiatan pembelajaran bisa saja berasal dari sekolah itu sendiri atau dari pihak lain. Pada dasarnya tidak menjadi masalah dari manapun asalnya media TIK yang sampai di sekolah. Dalam hal ini justru lebih penting lagi adalah bagaimana menyiasati agar media TIK yang telah tersedia di sekolah dapat dioptimalkan pemanfaatannya bagi kepentingan pembelajaran peserta didik. Beberapa contoh media TIK yang mulai banyak tersedia di pasaran adalah $\mathrm{CD} /$ kaset audio, VCD, dan internet. Sehubungan dengan semakin maraknya ketersediaan media TIK untuk kegiatan pembelajaran, baik di pasaran, yang diadakan sekolah sendiri maupun yang diterima sekolah dari berbagai pihak.

Perkembangan teknologi komunikasi dan informasi serta perubahan kurikulum di sekolah, telah berpengaruh terhadap proses relasi antara pendidik dengan peserta didik. Pembelajaran selama ini berpusat kepada guru telah berubah menjadi pembelajaran yang berpusat kepada peserta didik Molly Jhonson (Sudirman Siahaan 2009) menjelaskan karakteristik pembelajaran yang berpusat kepada peserta didik adalah: (1) guru lebih berperan sebagai fasilitator dalam kegiatan pembelajaran ketimbang sebagai penyaji pengetahuan, (2) pengelolaan kelas yang lebih kondusif terhadap kegiatan dan interaksi peserta didik yang mengarah kepada pengalaman belajar yang produktif, (3) peserta didik aktif dalam kegiatan yang berkaitan dengan pembelajaran ketimbang hanya duduk manis dan pasif selama kegiatan belajar berlangsung di dalam kelas, dan (4) membutuhkan investasi waktu dan energi untuk menerapkan model pembelajaran yang berfokus pada peserta didik.

Perubahan paradigma pembelajaran dan perkembangan teknologi informasi menyebabkan perubahan peran yang harus dijalankan guru dalam berhubungan dengan peserta didik. Selama berlangsungnya proses pembelajaran, guru diharapkan memahami dan mengetahui secara jelas arah perkembangan peserta didik, sehingga guru dapat memilih pendekatan yang menyenangkan serta inovatif dalam pembelajaran. Kegiatan-kegiatan yang 
bersifat memaksa dimodifikasi menjadi kegiatan menyenangkan dengan cara memberikan berbagai kesempatan kepada peserta didik untuk membuat kesimpulan/dan atau menjelaskan materi yang baru saja selesai dibahas. Peserta didik juga haruslah dikondisikan untuk mengajukan pertanyaan yang bersifat konstruktir sehubungan dengan materi yang dipelajari.

Di samping itu, melalui pembelajaran yang berpusat kepada peserta didik, diharapkan guru menggunakan berbagai media teknologi informasi untuk membantu peserta didik agar dapat menghubungkan berbagai pengetahuannya dengan alam nyata. Kondisi semacam ini dewasa ini sangat didukung dengan adanya perkembangan teknologi informasi yang sangat maraknya, baik yang sudah disediakan di sekolah maupun masyarakat. Untuk itu guru diharapkan dapat mendukung penyediaan sara prasarana yang diperlukan untuk itu di sekolah, begitu juga mendorong peserta didik menggunakan sarana-prasarana teknologi informasi yang tersedia di masyarakat untuk digunakan demi kelancaran pembelajaran. Perkembangan teknologi informasi dan perubahan paradigma pembelajaran telah merubah budaya guru serta peserta didik dalam pembelajaran. Guru dituntut merumuskan strategi pembelajaran yang bermakna untuk membuat peserta didik lebih aktif memanfaatkan sumber belajar dalam mencapai tujuan pembelajaran. Kemampuan guru merumuskan strategi pembelajaran yang bermakna sangat tergantung dari kreatifitas serta imajinasi mengablikasikan kondisi budaya masyarakat dalam pembelajaran. Budaya merupakan keseluruhan yang ada dalam masyarakat, menyangkut dengan gagasangagasan, ide-ide, nilai-nilai, pola tingkah laku serta benda hasil karya. Pembelajaran berwawasan budaya menjadikan siswa tidak terasing dan dapat mengaplikasikan berbagai ilmu pengetahuan yang diperoleh dengan kondisi yang ada di sekitar mereka.

Perkembangan teknologi komunikasi dan informasi serta perubahan kurikulum di sekolah, telah berpengaruh terhadap proses relasi antara pendidik dengan peserta didik. Pembelajaran selama ini berpusat kepada guru 
telah berubah menjadi pembelajaran yang berpusat kepada peserta didik. Perubahan paradigma pembelajaran dan perkembangan teknologi informasi menyebabkan perubahan peran yang harus dijalankan guru dalam berhubungan dengan peserta didik. Selama berlangsungnya proses pembelajaran, guru diharapkan memahami dan mengetahui secara jelas arah perkembangan peserta didik, sehingga guru dapat memilih pendekatan yang menyenangkan serta inovatif dalam pembelajaran. Kegiatan-kegiatan yang bersifat memaksa dimodifikasi menjadi kegiatan menyenangkan dengan cara memberikan berbagai kesempatan kepada peserta didik untuk membuat kesimpulan/dan atau menjelaskan materi yang baru saja selesai dibahas. Peserta didik juga haruslah dikondisikan untuk mengajukan pertanyaan yang bersifat konstruktir sehubungan dengan materi yang dipelajari.

\section{Sistem Penjaminan Mutu dan Jejaringan FIP-JIP}

Manajemen pendidikan tinggi dewasa ini, menekankan pentingnya otonomi institusi yang berlandaskan pada akuntabilitas, evaluasi, dan akreditasi dan bermuara pada peningkatan kualitas secara berkelanjutan. Di sisi lain, perkembangan globalisasi, kebutuhan masyarakat dan tuntutan persaingan yang semakin ketat, menuntut komitmen yang tinggi dari perguruan tinggi untuk menyelenggarakan pendidikan yang bermutu. Pendidikan bermutu ditunjukan untuk pencapaian tujuan dan kompetensi lulusan sesuai dengan standar yang diharapkan.

Berkaitan dengan uraian tersebut, penjaminan mutu FIP-JIP dari berbagai perguruan tinggi di Indonesia sangat diharapkan masyarakat Indonesia dalam upaya pengembangan SDM yang andal. Penjaminan mutu yang dimaksud dalam hal ini, adalah kesesuaian standar dengan harapan masyarakat pengguna berkaitan dengan kompetensi lulusan. Mutu lulusan FIP-JIP dimaksudkan sebagai pencapaian tujuan pendidikan dan kompetensi lulusan yang telah ditetapkan sesuai dengan rencana strategis masing-masing perguruan tinggi. Hal penting yang diperlukan untuk perwujudan mutu 
lulusan adalah pengelolaan pendidikan yang berorientasi pada peningkatan mutu secara berkesinambungan serta menjaga terpelihara siklus pengelolaan sesuai dengan harapan masyarakat pengguna. Pencapaian tujuan tidak akan lepas dari unsur masukan, proses, luaran, nilai dan derjat kebaikan dan kesempurnaan yang dihasilkan peguruan tinggi penyelenggara FIP-JIP tersebut.

Pewujudan mutu pendidikan dalam pengembangan SDM yang andal dari perguruan tinggi penyelenggara Fakultas Ilmu Pendidikan atau Jurusan Ilmu Pendidikan di Indonesia, diperlukan adanya system jaminan mutu yang andal. System jaminan mutu merupakan suatu system yang diimplimentasikan di lingkungan FIP-JIP untuk menjamin agar mutu pendidikan dapat dipertahankan serta ditingkatkan sesuai dengan rencana masing-masing perguruan tinggi. Sistem jaminan mutu ditujukan untuk mendorong masing-masing perguruan tinggi dalam pencapaian visi dan misi melalui penjaminan serta pelayanan bermutu, perbaikan mutu secara berkelanjutan serta penetapan tugas dan fungsi setiap komponen yang ada dalam penjaminan mutu.

Jaminan mutu perguruan tinggi penyelenggara Fakultas Ilmu Pendidikan atau Jurusan Ilmu Pendidikan tidak terlepas dari organisasi universitas itu sendiri, yaitu Universitas, Fakultas dan Jurusan. Penekanan fungsi tiap tingkat berbeda satu dengan lainnya. Universitas menjalankan fungsinya sebagai manajemen terpadu, sedangkan fakultas menjalankan fungsi penjaminan mutu serta jurusan berfungsi sebagai pengendali mutu. Berkaitan dengan hal itu, jaminan mutu universitas ditentukan oleh Rektor, Pimpinan Fakultas dan Pimpinan Jurusan/Prodi. Rektor pada tingkat universitas bertanggung jawab terhadap manajemen mutu terpadu, sedangkan Pimpinan Fakultas berfungsi sebagai jaminan mutu dan Pimpinan Jurusan bersama beberapa orang dosen yang diperbantukan menjalankan fungsinya sebagai pengendali mutu. 
Pengembangan program kegiatan peningkatan mutu FIP-JIP didasarkan oleh rencana strategis perguruan tinggi penyelenggara yang disertai oleh pembaharuan terhadap metode dan substansi pembelajaran serta peningkatan sarana dan prasarana pendukung. Pembelajaran yang didasarkan oleh pertimbangan perubahan paradigma pendidikan yang ditujukan kepada peserta didik (student learning) diharapkan menjadi pertimbangan utama. Ruang lingkup system manajemen mutu yang diharapkan dari JIP-FIP berkaitan dengan penyelenggaraan Tridharma Perguruan Tinggi, yaitu : bidang pendidikan pengajaran, penelitian dan pengabdian kepada masyarakat.

Strategi pelaksanaan jaminan mutu berlangsung secara berkelanjutan dalam pelaksanaan pendidikan sejak awal mahasiswa, lulus serta wisuda. Sistim jaminan mutu yang diterapkan di lingkungan FIP-JIP hendaknya mencakup standar akademik, mutu pembelajaran, mutu pelayanan, tingkat pencapaian, mutu penelitian dan pengabdian kepada masyarakat, serta tingkat kepuasan masyarakat pengguna. Pelaksanaan jaminan mutu didasarkan oleh SOP yang terus menerus bertambah serta disempurnakan sesuai dengan kebutuhan. Panduan pelaksanaan jaminan mutu perlu disiapkan bersama dan disosialisasikan untuk seluruh anggota FIP-JIP baik lisan maupun tertulis. Standar mutu pendidikan sebagai manual mutu FIP-JIP, diharapkan menyangkut dengan : (1) visi, (2) misi, (3) tujuan pendidikan dan kurikulum, (4) input, (5) perencanaan dan review kurikulum, (6) dosen, (7) sumber belajar dan lingkungan belajar, (8) organisasi pembelajaran, (9) proses pembelajaran, (10) evaluasi , (11) dukungan terhadap prestasi akademik mahasiswa serta (12) outcomes dan kendali mutu.

Perwujudan jaminan mutu FIP-JIP, diperlukan adanya kebijakan mutu yang bertujuan untuk menghasilkan lulusan yang bermutu dan memberikan kepuasan kepada masyarakat pengguna. Kebijakan mutu tersebut diharapkan dibangun melalui komitmen, keunggulan, kebersamaan, keikhlasan serta kerja keras masing-masing perguruan tinggi penyelenggara. Penyelenggaraan 
pendidikan di lingkungan FIP-JIP secara konsisten hendaknya menerapkan standar penyelenggaraan pendidikan tinggi Indonesia, yaitu :

1. Kepemimpinan

Fakultas Ilmu Pendidikan atau Jurusan Ilmu Pendidikan masingmasing perguruan tinggi hendaknya menerapkan secara konsisten mekanisme kepemimpinan berdasarkan kepatutan dan kepantasan, mulai dari pemilihan pimpinan laboratorium sampai kepada dekan. Kepemimpinan di tingkat satuan tersebut, diharapkan dapat merangsang dan menumbuhkembangkan kepemimpinan pada unit kerja, seperti : laboratorium, jurusan, prodi yang diarahkan untuk pencapaian visi, misi universitas serta fakultas dengan mengutamakan kesadaran akan mutu proses untuk memenuhi harapakan masyarakat pengguna. Kepemimpinan harus dapat diukur berdasarkan pelaksanaan renstra yang telah disusun, mencakup : (1) mekanisme pemilihan pimpinan, (2) monitoring dan penggunaan data dalam perjalanan kepemimpinan.

2. Kemahasiswaan

Mahasiswa merupakan stakeholders internal yang secara langsung dikenai oleh dampak perlaksanaan pendidikan. Sehubungan dengan hal itu, seluruh fasilitas yang disediakan harus dioptimalkan untuk pengembangan seluruh potensi masiswa. Peningkatan prestasi mahasiswa menggambarkan mutu proses pelayanan pendidikan, yang didukung oleh penyediaan unit-unit kegiatan untuk membangun kegiatan mahasiswa menjadi dinamik. Ukuran mutu kemahasiswaan terlihat dari : (1) berjalannya berbagai kegiatan di lingkungan unit-unit kemahasiswaan, (2) adanya kode etik dan aturan yang menjamin berjalannya kegiatan kemahasiswaan yang dinamis, (3) aktifnya kegiatan pengembangan minat dan bakat, (4) aktifnya kegiatan kemahasiswaan dalam bidang ilmiah di tingkat local, regional, nasional dan internasional, (5) berjalannya sistim pelacakan lulusan dan kerjasama alumni. 
3. Sumber Daya Manusia

Sumber daya manusia di lingkungan FIP-JIP penyelenggara adalah dosen, teknisi, serta tenaga adminstrasi lainnya. Sumber daya manusia yang dimiliki harus dikelola sehingga menjamin terciptanya proses pendidikan bermutu. Sehubungan dengan hal itu, mutu pengelolaan SDM FIP-JIP masing-masing perguruan tinggi dapat diukur melalui : (1) rasio dosen dengan masiswa, (2) kualifikasi dosen, (3) perencanaan dan pengembangan, (4) sistim rekrutmen dan seleksi, (5) orientasi dan penempatan, (6) sistim pengembangan karir, (7) sistim penghargaan, dan (8) sistim pengaturan renumerasi.

4. Kurikulum

Kurikulum merupakan rancangan seluruh kegiatan pembelajaran sebagai rujukan program studi dalam merencanakan, melaksanakan, memonitoring dan mengevaluasi seluruh kegiatan untuk mencapai tujuan program studi. Kurikulum dijadikan acuan dasar dalam pembentukan dan penjaminan tercapainya komptensi lulusan dalam setiap program akademik pada tingkat program studi. Pencapaian pelaksanaan kurikulum taat azas diperlukan adanya perencanaan pengembangan dan pemutakhiran kurikulum secara berkala dan berkesinambungan serta berjalannya kegiatan perencanaan, pengembangan dan pemutakhiran kurikulum tersebut.

5. Sarana dan Prasarana

Sarana prasarana merupakan unsur penunjang dalam pelasksanaan Tridharma Perguruan Tinggi, meliputi bangunan, peralatan dan sistim pengamnan asset. Sehubungan dengan hal itu, setiap lembaga harus memiliki : (1) sistim pengelolaan dan sarana dan prasarana, (2) kebijakan, pedoman, panduan dan peraturan yang jelas tentang keamanan dan keselamatan penggunaan sarana dan prasarana, dan (3) sistim pengelolaan income generating. 
6. Pendanaan

FIP-JIP masing-masing perguruan tinggi diharapkan mampu menjamin pendanaan yang memadai untuk penyelenggaraan kegiatan. Usaha-usaha penggalangan dana harus mengacu kepada visi dan misi yang tidak bertentangan dengan peraturan serta perundangan yang berlaku. FI-JIP masing-masing perguruan tinggi harus memiliki sistim pengelolaan keuangan yang sehat, transparan dan akuntabel, dengan memiliki : (1) sistim audit dan pemanfaatan keuangan, (2) mekanisme perencanaan dan penetapan biaya pendidikan dengan mempertimbangkan proporsi dana yang dialokasikan untuk program akademik dengan investasi pada aspek fisik, sarana dan prasarana.

7. Tatapamong

Tata pamong (governance) mencakup system, stuktur organisasi dan makanisme yang menjamin pengelolaan secara transparan dan akuntabel. Berjalanya system tata pamong ditunjukan oleh : (1) adanya unit tata pamong dalam bentuk struktur dengan fungsi dan wewenang yang jelas, sesuai dengan kebutuhan institutisi serta peraturan yang berlaku, (2) adanya Renstra dan Renop, (3) adanya SOP yang memberikan gambaran tentang mekanisme dalam melaksanakan perencanaan, pengembangan dan implementasi kebijakan pada setiap unit kerja, juru dan laboratorium, (4) adanya laporan kinerja setiap unit kerja, jurusan, laboratorium sebagai bentuk akuntabilitas public.

8. Sitim Pengelolaan

Sistim pengelolaan merupakan desain majemen dari setiap uni kerja, jurusan, laboratorium agar proses pelayanan pendidikan dapat berjalan dengan baik. Untk itu setiap unit tata kerja, yaitu jurusan dan laboratorium harus memiliki : (1) rancangan nalisis jabatan, (2) Job deskripsi, (3) prosedur kerja, (4) adanya sistim monitoring tiap unit tata pamong, yaitu jurusan, laboraotirum. 
9. Sistim Pembelajaran

Sistim pembelajaran merupakan strategi pencapaian visi dan misi fakultas dan universitas. Sistim pembelajaran yang dikembangkan secara nasional dan universitas serta menjadi acuan bagi jurusan, laboratorium dalam menjalankan proses pembelajaran serta kegiatan akademik lainnya. Untuk menjalankan kegiatan tersebut fakultas harus menyediakan pedoman akademik yang bersikan kebijakan, peraturan, kode etik, norma dan nilai akademik.

10. Suasana Akademik

Suasana akademik merupakan kondisi yang dapat menumbuhkembangkan semangat peningkatan mutu akademik, interaksi diantara dosen dan mahasiswa, kuantitas dan kualitas kegiatan akademik, mendorong pengembangan profesionalisme, kebebasan akademik, kebebasan mimbar akademik serta penghormatan kepada kebenaran dan semangat belajar secara terus menerus. Perwujudan suasana akademik yang kondusif setiap lembaga diharuskan memiliki: (1) system penghargaan bagi dosen dan mahasiswa, (2) perencanaan kegiatan akademik yang terjadwal untuk meraih keunggulan akademik di dalam dan diluar kampus, seperti : penyelenggaraan seminar, lokakarya, symposium, demonstrasi/pameran dan lomba karya ilmiah dosen dan mahasiswa serta keikutsertaan dosen dan mahasisa dalam forum ilmiah di tingkat nasional dan internasional.

\section{Sistim Infomasi}

Sistim informasi merupakan sistim yang mendukung poengelolaan dan peningkatan mutu program akademik. Melalui system sinformasi akan dijamin pengumpulan data, analisis, penyimpanan dan pengambilan kembali data, presentasi data dan informasi serta komunikasi dengan pihak berkepentingan. Informasi yang dikelola meliputi informasi akademik kemahasiswa, sumber dayta manusia, prasarana dan sarana, 
administrasi dan keuangan serta data lain yang akan menunjang proses pendidikan di seluruh unit kerja, jurusan, laboratorium. Setiap insitutisi diharapkan dapat mengembangkan sistim informasi terpadu yang dapat diakses melalui internet dan system jaringan.

\section{Sistim Penjaminan Mutu Internal}

Sistim penjaminan mutu internal yang ada di lingkungan FIP-JIP masing-masing perguruan tinggi diharapkan mencerminkan adanya pengorgasnisasian dan manual mutu yang memuat pernyataan mutu sebagai komitmen, kebijakam mutu, prosedur mutu dan target mutu yang harus dicapai oleh tiap unit kerja, jurusan dan laboratorium.

13. Lulusan

Lulusan merupakan luaran yang harus memiliki kompetensi akademik maupun sofl skills yang ditunjukan oleh kinerja mereka di masyarakat sesuai sebagai sasaran mutu. Sehubungan dengan hal itu Fakultas Ilmu Pendidikan atau Jurusan Ilmu Pendidikan masing-masing perguruan tinggi diharapkan telah melakukan pemetaan lulusan dan membantu lulusan dalam mendapatkan pekerjaan serta meningkatkan interaksi antara lulusan dengan Fakultas Ilmu Pendidikan atau Jurusan Ilmu Pendidikan. Sehubungan dengan hal itu, FIP-JIP dari masingmasing perguruan tinggi diharapkan telah mempunyai mekanisme yang menjamin pemanfaatan hasil evaluasi dan pelacakan lulusan.

14. Penelitian dan Pengabdian Kepada Masyarakat

Penelitian dan pengabdian kepada masyarakat merupakan bagian dari Tridharma Perguan Tinggi yang akan dijalankan oleh seluruh civitas akademika. Penjaminan pelaksanaan penelitian dan pengabdian masyarakat, masing-masing lembaga diharuskan : (1) membuat sitim agar mampu memberikan dorongan kepada dosen dan mahasiswa untuk melakukan berbagai kegiatan penelitian dan pengabdian kepada masyarakat, (2) memfasilitasi agar dosen melakukan penelitian dan 
pengabdian kepada masyarakat, (3) melakukan upaya-upaya untuk memperoleh dana penelitian dan pengabdian kepada masyarakat, memfasilitasi untuk melakukan publikasi karya ilmiah dan memperleh paten atau hak kekayaan intelektual.

\section{Program Studi}

FIP-JIP dari setiap perguruan tinggi diharapkan mendorong program studi agar memiliki tingkat efektifitas dalam pengelolaan dan mencapai pengakuan public dalam bentuk pencapaian akreditasi nasional maupun internasional.

Pencapaian standar pendidikan tersebut di atas, ditentukan jaminan mutu FIP-JIP secara internal sesuai dengan situasi dan kondisi masing perguruan tinggi. Peningkatan jaminan mutu masing-masing perguruan sangat ditentukan oleh organisasi mutu secara eksternal melalui jejaringan paguyuban FIP-JIP se Indonesia. Kebutuhan akan peningkatan mutu melalui jejaringan ini didasarkan oleh berbagai fenomena yang ditemui sejak berdirinya FIP-JIP dari berbagai perguruan tinggi di Indonesia, masingmasing memiliki kekhasan dan mengalami perkembangan yang berbeda satu dengan lainnya. Keberbedaan perkembangannya dalam mencapai hasil yang maksimal, salah satu kekayaan dan disebabkan oleh kondisi geografis, SDM serta sarana dan prasarana pendukung lainnya. Mempertimbangkan berbagai kekhasan serta keterbatasan tersebut, maka sangat penting bagi FIP-JIP dari berbagai perguruan tinggi di Indonesia untuk memiliki jaringan yang mampu menjembatani berbagai permasalahan, sehingga kolaborasi dan kerjasama dalam pelaksanaan Tridhama perguruan tinggi dapat dilaksanakan tanpa halangan oleh berbagai keterbatasan dalam perwujudan jaminan mutu beserta kegiatan dan ruang lingkupnya.

Jaringan FIP-JIP merupakan suatu sistem hubungan antar perguruan tinggi yang menyelenggarakan Fakultas Ilmu Pendidikan atau Jurusan Ilmu Pendidikan se Indonesia, yang diatur dan disusun menurut berbagai bentuk 
persetujuan yang memungkinkan komunikasi dan pengiriman informasi secara berkelanjutan, pertukaran keahlian serta sumber daya lainnya. Jejaringan JIP-FIP ditujukan membangun SDM dalam peningkatan pelaksanaan Tri Darma Perguruan Tinggi, meliputi bidang pengelolaan, pendidikan dan pengajaran serta pelatihan, penelitian dan pengabdian kepada masyarakat.

Jejaringan FIP-JIP akan memberi manfaat dalam menyediakan informasi yang lebih mutakhir serta dapat digunakan secara fleksibel dalam pengelolaan serta civitas akademika lainnya sesuai kebutuhannya dalam melaksanakan Tridhama Perguruan Tinggi. Peningkatan jaringan FIP-JIP didorong oleh semakin meningkatnya kebutuhan masyarakat akan kualitas lulusan yang memiliki kompetensi serta daya saing yang tinggi, kemajuan serta perkembangan teknologi informasi yang memungkinkan kerjasama berjalan lebih efektif dan efesien, penghematan biaya, fasilitas serta tenaga yang ada. Ruang lingkup kerjasama diharapkan menyangkut dengan pertukaran tenaga pengajar, pembinaan dan pengembangan staf pengajar, pengembangan program pendidikan dan pelatihan, penyelenggaraan penelitian dan pengabdian kepada masyarakat, penulisan buku serta publikasi ilmiah melalui jurnal bersama.

Peningkatan jaringan FIP-JIP antar perguruan tinggi dapat dilakukan melalui kerjasama dengan FIP-JIP yang perguruan tingginya tergabung dalam program INHERENT. Program INHERENT telah dikembangkan Direktorat Jenderal Pendidikan Tinggi pada tahun 2006, dengan membangun suatu jaringan komputer antar perguruan tinggi. Di sisi lain jejaringan dapat juga dilakukan melalui pemanfaatan teknologi informasi dan komunikasi yang ada, sehinga pada gilirannya FIP-JIP diharapkan dapat memacu penggunaan sumber daya secara bersama, berupa sumber daya informasi maupun sumber daya komputasi serta sumber daya manusia. Sumber daya informasi, seperti perpustakaan digital, pangkalan data, atau repository informasi diharapkan dapat dimanfaatkan secara bersama dengan memanfaatkan TIK yang ada 
dengan memperhatikan aturan universal, seperti hak cipta atau hak atas kekayaan intelektual lainnya.

Di samping itu, jejaringan FIP-JIP dapat dilakukan melalui Web Site dan Milling List bersama, yang dapat dimanfaatkan dalam pertukaran berbagai informasi ilmiah bagi seluruh sivitas akademika. Melalui kegiatan yang dilaksanakan melalu jaringan antara FIP-JIP, segala permasalahan dalam pemenuhan perubahan akan tuntutan masyarakat terhadap lulusan FIPJIP dapat diatasi. Melalui kegiatan itu pada gilirannya diharapkan mutu lulusan yang dihasilkan perguruan tinggi penyelenggara FIP-JIP dapat ditingkatkan sesuai dengan kebutuhan masyarakat pengguna.

\section{Penutup}

Pendidikan bermutu berkaitan dengan pencapaian tujuan dan kompetensi lulusan sesuai dengan standar yang diharapkan, dengan menerapkan system jaminan mutu yang andal. Sistem jaminan mutu ditujukan untuk mendorong pencapaian visi dan misi melalui penjaminan serta pelayanan bermutu, perbaikan mutu secara berkelanjutan serta penetapan tugas dan fungsi setiap komponen yang ada. Pengembangan program kegiatan peningkatan mutu didasarkan oleh rencana strategis yang disertai oleh pembaharuan terhadap metode dan substansi pembelajaran serta peningkatan sarana dan prasarana pendukung. Ruang lingkup system manajemen mutu berkaitan dengan penyelenggaraan Tridharma Perguruan Tinggi, yaitu : bidang pendidikan pengajaran, penelitian dan pengabdian kepada masyarakat. Sistim jaminan mutu mencakup : standar akademik, mutu pembelajaran, mutu pelayanan, tingkat pencapaian, mutu penelitian dan pengabdian kepada masyarakat serta tingkat kepuasan masyarakat pengguna. Pelaksanaan jaminan mutu didasarkan oleh SOP yang terus menerus bertambah serta disempurnakan sesuai dengan kebutuhan.

Jejaringan FIP-JIP se Indonesia dalam penyelenggaraan pendidikan bermutu memuat tentang sistem kerja yang terintegrasi secara 
menyeluruh. Jaringan FIP-JIP merupakan suatu sistem hubungan antar perguruan tinggi yang menyelenggarakan Fakultas Ilmu Pendidikan atau Jurusan Ilmu Pendidikan, yang diatur dan disusun menurut berbagai bentuk persetujuan yang memungkinkan komunikasi dan pengiriman informasi secara berkelanjutan, pertukaran keahlian serta sumber daya lainnya. Jejaringan FIP-JIP akan memberi manfaat dalam menyediakan informasi yang lebih mutakhir serta dapat digunakan secara fleksibel dalam pengelolaan serta civitas akademika lainnya sesuai kebutuhannya. Ruang lingkup kerjasama diharapkan menyangkut dengan pertukaran tenaga pengajar, pembinaan dan pengembangan staf pengajar, pengembangan program pendidikan dan pelatihan, penyelenggaraan penelitian dan pengabdian kepada masyarakat, penulisan buku serta publikasi ilmiah melalui jurnal bersama. 


\section{DAFTAR PUSTAKA}

Bayles, Michael D. (2001) :. Professional Ethics, California: Wadsworth Publishing Company.

Buchori, Mochtar (2001) : Pendidikan Antisipatoris. Yogyakarta: Kanisius.

Ditjen Dikti Depdikbud : (1982) Wawasan Kependidikan Guru, Proyek Pengembangan Institusi Pendidikan Tinggi. Jakarta : Ditjen Dikti Depdikbud.

Freiri, Paulo (2002) : Politik Pendidikan (Kebudayaan, Kekuasaan, dan Pembebasan). Yogyakarta: Pustaka Pelajar Offset.

Hasibuan, J.J., Ibrahim, dan A.J.E. Toen Lioe (2001) : Proses Belajar Mengajar. Bandung: PT Remaja Rosdakarya.

Ibrahim. (2001) Inovasi Pendidikan. Jakarta: Depdikbud Dikti P2LPTK.

Institut Pertanian Bogor (2004) : Sistem Jaminan Mutu Pendidikan Institut Pertanian Bogor. Bogor : Institut Pertanian Bogor.

Miarso, Yusufhadi (2004) : Teknoogi Komunikasi Pendidikan (Pengertian dan Penerapannya di Indonesia). Jakarta: Pustekkom Dikbud dan CV Rajawali.

O’neil, William F (2002) : Ideologi-ideologi Pendidikan. Yogyakarta: Pustaka Pelajar.

Rogers, Everett, M (2003) : Difusi Inovasi. (Third Edition). New York: The Free Press.

Spargo, Edward (2003) : The College Student, Reading and Study Skills. Rhode Island: Jamestown Publishers.

Tilaar, H.A.R (2000) : Paradigma Baru Pendidikan Nasional. Jakarta: Rineka Cipta. 
Universitas Negeri Padang. (2009) : Manual Mutu dan Prosedur Mutu Fakultas teknik Universitas Negeri Padang. Padang : Universitas Negeri Padang.

Universitas Muhammadiyah Surakarta (2007) : Manual Mutu Akademik Pendidikan Universitas Muhammadiyah Surakarta. Surakarta : Universitas Muhammadiyah Surakarta. 